\title{
HUBUNGAN DUKUNGAN SUAMI DENGAN PEMILIHAN METODE KONTRASEPSI PADA PASANGAN USIA SUBUR DI PUSKESMAS SUNYARAGI KOTA CIREBON TAHUN 2020
}

\author{
Rany Muliany Sudirman, Rina Herdiana \\ STIKes Kuningan \\ rany_yora@yahoo.com
}

\begin{abstract}
Abstrak
Alat kontrasepsi $(\mathrm{KB})$ memiliki berbagai macam jenis metode dengan kekurangan dan kelebihan dalam penggunaannya. Dukungan suami sangat diperlukan karena dapat memberikan motivasi dan kenyamanan dalam memilih alat kontrasepsi. Dari 10 orang ibu akseptor KB di Kelurahan Sunyaragi RT/RW 02/03 Kecamatan Kesambi Kota Cirebon, diketahui bahwa 8 dari 10 ibu menggunakan KB atas sepengetahuan suaminya. Tujuan dari penelitian ini adalah untuk mengetahui hubungan dukungan suami terhadap pemilihan metode kontrasepsi pada pasangan usia subur di Puskesmas Sunyaragi Kecamatan Kesambi Kota Cirebon Tahun 2020.

Jenis penelitian analitik dengan rancangan cross sectional. Populasi dalam penelitian ini adalah 1.033 pasangan usia subur yang menjadi akseptor di Puskesmas Sunyaragi Kecamatan Kesambi Kota Cirebon Tahun 2020. Teknik sampel dalam penelitian ini adalah Purposive Sampling, dengan rumus slovin didapat jumlah sampel penelitian sebanyak 43 orang. Dalam pengumpulan data peneliti menggunakan kuesioner serta handphone sebagai alat bantu berkomunikasi dengan para responden. Uji analisis yang dipakai uji chi Square.

Hasil penelitian didapatkan bahwa lebih dari separuh responden mendapat dukungan yang positif dari suami (51,2\%). Hampir sebagian responden memilih kontrasepsi pil KB $(39,5 \%)$. Hasil analisis bivariat dengan chi-square diperoleh $\mathrm{p}$ value $=0,004$.

Simpulan penelitian, terdapat hubungan yang bermakna antara dukungan suami dengan pemilihan metode kontrasepsi pada pasangan usia subur di Puskesmas Sunyaragi Kota Cirebon Tahun 2020. Saran agar suami memberikan support kepada istri dalam pemilihan metode kontrasepsi yang tepat.
\end{abstract}

Kata Kunci : Dukungan suami, Kontrasepsi, PUS 
JOURNAL OF NURSING PRACTICE AND EDUCATION

VOL. 01 NO. 01, DESEMBER 2020
Ciptaan disebarluaskan di bawah

Lisensi Creative Commons Atribusi-

NonKomersial-BerbagiSerupa 4.0

Internasional.

\section{Pendahuluan}

Indonesia merupakan salah satu Negara berkembang di dunia dengan berbagai jenis masalah yang dihadapinya salah satunya di bidang kependudukan yaitu masih tingginya pertumbuhan penduduk. Pemerintah dalam upaya meningkatkan kesejahteraan bangsa telah dan sedang melakukan pembangunan dalam segala bidang untuk mengatasi masalah kependudukan. Salah satu upaya yang perlu dilakukan pemerintah untuk mengatasi masalah kependudukan adalah program keluarga berencana. Program Keluarga Berencana adalah upaya peningkatan kepedulian dan peran serta masyarakat melalui pendewasaan usia perkawinan, pengaturan kelahiran, pembinaan ketahanan keluarga, peningkatan kesejahteraan keluarga kecil, bahagia dan sejahtera.

Menurut Badan Pusat Statistik (2015), jumlah penduduk Indonesia berdasarkan hasil Survei Penduduk Antar Sensus (SUPAS) 2015 sebanyak 255,18 juta jiwa. Dibandingkan dengan sensus maupun survei penduduk sebelumnya, dapat dilihat bahwa jumlah penduduk Indonesia terus mengalami peningkatan. Dalam jangka waktu 15 tahun yaitu tahun 2000 hingga 2015, jumlah penduduk Indonesia mengalami penambahan sekitar 50,06 juta jiwa atau rata-rata 3,33 juta setiap tahun.

TFR (Total Fertility Rate) adalah jumlah dari angka kelahiran menurut kelompok umur dan merupakan ringkasan ukuran dari tingkat fertilitas. Angka ini menggambarkan ratarata jumlah anak yang akan dilahirkan oleh seorang wanita pada akhir masa reproduksinya. TFR secara nasional menunjukan tren yang terus menurun, dari angka 5,61 anak pada tahun 1971 menjadi 2,41 anak pada tahun 2010 dan menurun lagi menjadi 2,28 anak pada tahun 2015. Angka fertilitas menurut kelompok umur (Age Specific Fertility Rate atau ASFR) untuk periode 3 tahun terakhir sebelum SUPAS 2015 menunjukan banyaknya kelahiran pada perempuan kelompok usia tertentu per 1000 perempuan pada kelompok usia tersebut. Pada kelompok usia muda anak yang dilahirkan rendah, semakin bertambah umur semakin banyak, dan puncaknya pada perempuan umur 25-29 tahun, kemudian setelah kelompok umur tersebut anak yang dilahirkan mengalami penurunan. 
JOURNAL OF NURSING PRACTICE AND EDUCATION

VOL. 01 NO. 01, DESEMBER 2020
Ciptaan disebarluaskan di bawah

Lisensi Creative Commons Atribusi-

NonKomersial-BerbagiSerupa 4.0

Internasional.

Rata-rata umur kawin pertama (Singulate Mean Age at Marriage) merupakan salah satu indikator untuk menggambarkan tingkat fertilitas, karena semakin muda seseorang mengalami perkawinan maka semakin panjang masa reproduksinya, sehingga akan semakin besar peluang melahirkan anak yang lebih banyak. Hasil SUPAS 2015 menyajikan informasi tentang prevalensi pemakaian kontrasepsi di antara wanita berstatus kawin atau hidup bersama berusia 15-49 tahun, pada tahun 2015 terdapat 61,6\% wanita berstatus kawin atau hidup bersama usia 15 - 49 tahun yang menggunakan alat atau cara KB. Wanita yang menggunakan alat atau cara KB tersebut, sebagian besar diantaranya menggunakan metode kontrasepsi modern $(98,5 \%)$ dan 1,5\% menggunakan metode kontrasepsi tradisional. Di antara cara metode yang dipakai, suntik KB merupakan alat kontrasepsi terbanyak digunakan oleh wanita berstatus kawin atau hidup bersama $(59,0 \%)$, diikuti oleh pil KB hampir 21,6\%. Pemakaian alat kontrasepsi pada wanita kawin atau hidup bersama tertinggi pada kelompok umur 35-39 tahun yaitu sebesar 67,3\% dan terendah pada kelompok umur 15-19 tahun sebesar 45,2\%. Wanita dari semua umur cenderung untuk memakai alat kontrasepsi modern jangka pendek seperti suntikan dan pil KB.

Salah satu upaya pemerintah dalam menekan laju pertumbuhan penduduk Indonesia adalah dengan program Keluarga Berencana (KB). Program KB yang ditujukan untuk menekan laju pertumbuhan penduduk adalah dengan mengajak seluruh masyarakat pasangan usia subur untuk menjadi akseptor KB. Program KB tidak hanya bertujuan untuk mengendalikan laju pertumbuhan penduduk, melainkan juga untuk memenuhi permintaan masyarakat akan pelayanan KB dan kesehatan reproduksi (KR) yang berkualitas, menurunkan angka kematian ibu (AKI) dan angka kematian bayi (AKB) serta penanggulangan masalah kesehatan reproduksi untuk membentuk keluarga kecil berkualitas. Undang-undang nomor 52 Tahun 2009 tentang perkembangan kependudukan dan pembangunan keluarga menyebutkan bahwa Keluarga Berencana (KB) adalah upaya mengatur kelahiran anak, jarak dan usia ideal melahirkan, mengatur kehamilan, melalui promosi, perlindungan, dan bantuan sesuai dengan hak reproduksi untuk mewujudkan keluarga yang berkualitas (Yusuf, 2020).

Prevalensi KB di Jawa Barat Pada Tahun 2017 berdasarkan Badan Pusat Statistik Provinsi Jawa Barat tercatat 9,333,302 juta jiwa pasangan usia subur dan jumlah akseptor KB 
JOURNAL OF NURSING PRACTICE AND EDUCATION

VOL. 01 NO. 01, DESEMBER 2020
Ciptaan disebarluaskan di bawah

Lisensi Creative Commons Atribusi-

NonKomersial-BerbagiSerupa 4.0

Internasional.

Aktif di Jawa Barat yaitu mencapai angka 1029212 dengan metode KB yang didominasi oleh peserta KB suntik (562,771), Pil KB (244867), Implan (79,773), Kondom (22,884), MOP (6,654), MOW (17,798), dan IUD (93,051). Sedangkan di Kota Cirebon pada tahun 2019 tercatat jumlah Pasangan Usia Subur (PUS) yaitu 41,690 jiwa dan jumlah akseptor aktif di Kota Cirebon yaitu 496,578 dengan metode KB IUD sebanyak $(3,399)$, MOW $(2,126)$, MOP (36), Kondom (435), Implan (1,278), KB Suntik (15,747), dan Pil KB (3,028). Data akseptor KB di Puskesmas Sunyaragi pada awal tahun 2020 tercatat 1.033 peserta KB dengan metode alat kontrasepsi yang digunakan yaitu IUD sebanyak 194 orang, MOW sebanyak 86 orang, kondom 18 orang, implan sebanyak 41 orang, pil 92 orang dan KB suntik sebanyak 602 orang.

Pasangan usia subur (PUS) adalah pasangan suami istri yang istrinya berumur antara 15 sampai dengan 49 tahun atau pasangan suami istri yang istri berumur kurang dari 15 tahun dan sudah haid atau istri berumur lebih dari 50 tahun, tetapi masih haid (Kadarisman \& Kurniawati, 2014). PUS yang menjadi peserta KB adalah pasangan usia subur yang suami/istri nya sedang memakai atau menggunakan salah satu alat atau cara kontrasepsi modern pada tahun pelaksanaan pendataan keluarga (BKKBN Provinsi Jawa Barat, 2020).

Suami merupakan peranan penting sebagai kepala keluarga yang mempunyai hak untuk mendukung atau tidak mendukung apa yang dilakukan istri. Peran suami dalam keluarga sangat dominan dan memegang kekuasaan dalam pengambilan keputusan apakah istri akan menggunakan kontrasepsi atau tidak. Suami menjadi individu yang berperan sebagai dukungan bagi istri dalam memilih menggunakan alat kontrasepsi yang dipilih sehingga dukungan suami sangat diperlukan karena dapat memberikan motivasi dan kenyamanan dalam memilih menggunakan alat kontrasepsi atau bahkan menghentikannya.

Dukungan suami merupakan informasi verbal atau non verbal, saran, bantuan yang nyata atau tingkah laku yang diberikan oleh pasangan hidup resmi seorang wanita (istri). Dalam melaksanakan Keluarga Berencana, dukungan suami sangat diperlukan. Seperti diketahui, bahwa di Indonesia keputusan suami dalam mengizinkan istri adalah pedoman penting bagi istri untuk menggunakan alat kontrasepsi. Dukungan suami sangat diperlukan 
JOURNAL OF NURSING PRACTICE AND EDUCATION

VOL. 01 NO. 01, DESEMBER 2020
Ciptaan disebarluaskan di bawah

Lisensi Creative Commons Atribusi-

NonKomersial-BerbagiSerupa 4.0

Internasional.

karena dapat memberikan motivasi dan kenyamanan dalam memilih menggunakan alat kontrasepsi.

Berdasarkan hasil wawancara terhadap 10 orang ibu akseptor $\mathrm{KB}$ di kelurahan sunyaragi rt/rw 02/03 diketahui bahwa 8 dari 10 ibu menggunakan KB atas sepengetahuan suaminya, KB yang digunakan oleh 5 orang ibu akseptor KB adalah KB suntik dengan alasan praktis karena suntik dilakukan 3 bulan sekali dan 3 diantaranya menggunakan pil KB dengan alasan tidak menyukai tindakan medis berupa suntik dan lain sebagainya, sedangkan 2 dari 10 orang ibu akseptor KB menggunakan IUD tanpa sepengetahuan suaminya karena suami bekerja di luar kota dan cenderung tidak peduli dengan masalah pemilihan alat kontrasepsi yang digunakan ibu.

Berdasarkan latar belakang diatas, peneliti tertarik untuk melakukan penelitian tentang hubungan dukungan suami terhadap pemilihan metode kontrasepsi pada pasangan usia subur di Puskesmas Sunyaragi Kecamatan Kesambi Kota Cirebon Tahun 2020.

\section{Bahan Dan Metode}

Jenis penelitian yang digunakan adalah penelitian analitik dengan rancangan cross sectional. Penelitian ini dilakukan untuk melihat hubungan antara dukungan suami dengan pemilihan metode kontrasepsi pada pasangan usia subur di Puskesmas Sunyaragi Kecamatan Kesambi Kota Cirebon Tahun 2020. Populasi dalam penelitian ini adalah 1.033 klien pasangan usia subur yang menjadi akseptor di Puskesmas Sunyaragi Kecamatan Kesambi Kota Cirebon Tahun 2020. Teknik sampel dalam penelitian ini adalah Purposive Sampling dan dengan rumus slovin didapatkan jumlah sampel sebanyak 43 orang. Instrumen penelitian yang digunakan untuk pengumpulan data untuk variabel bebas maupun variabel terikat menggunakan kuesioner atau angket. Analisis data yang dilakukan pada penelitian ini adalah analisis univariat dan analisis bivariat dengan uji chi square. 


\section{Hasil Penelitian}

Tabel 1 Distribusi Frekuensi Dukungan Suami di Puskesmas Sunyaragi Kota Cirebon

Tahun 2020

\begin{tabular}{cccc}
\hline No. & Tingkat Dukungan Suami & Frekuensi (f) & Presentase (\%) \\
\hline 1. & Dukungan Tinggi & 3 & 7 \\
2. & Dukungan Sedang & 29 & 67,4 \\
3. & Dukungan Rendah & 11 & 25,6 \\
& Jumlah & $\mathbf{4 3}$ & $\mathbf{1 0 0 , 0}$ \\
\hline
\end{tabular}

sebagian besar responden (istri) mendapat dukungan yang sedang dari suami, yaitu sebanyak 29 responden $(67,4 \%)$.

Tabel 2 Distribusi Frekuensi Pemilihan Metode Kontrasepsi pada Pasangan usia Subur di Puskesmas Sunyaragi Kota Cirebon Tahun 2020

\begin{tabular}{cccc}
\hline No. & $\begin{array}{c}\text { Pilihan } \\
\text { Kontrasepsi }\end{array}$ & Frekuensi (f) & Presentase (\%) \\
\hline 1. & Pil KB & 17 & 39,5 \\
2. & KB Suntik & 14 & 32,6 \\
3. & IUD & 1 & 2,3 \\
4. & Implan & 8 & 18,6 \\
5. & MOW & 3 & 7,0 \\
& Jumlah & $\mathbf{4 3}$ & $\mathbf{1 0 0 , 0}$ \\
\hline
\end{tabular}

Dari 43 responden, kebanyakan dari responden menggunakan atau memilih kontrasepsi Pil KB yaitu sebanyak 17 responden (39,5\%).

Tabel 3 Hubungan Dukungan Suami dengan Pemilihan Metode Kontrasepsi pada

Pasangan usia Subur di Puskesmas Sunyaragi Kota Cirebon Tahun 2020

\begin{tabular}{|c|c|c|c|c|c|c|c|c|c|c|c|c|c|c|}
\hline \multirow{3}{*}{ No. } & \multirow{3}{*}{$\begin{array}{c}\text { Tingkat } \\
\text { Dukungan } \\
\text { Suami }\end{array}$} & \multicolumn{12}{|c|}{ Pilihan Metode Kontrasepsi } & \multirow{3}{*}{$\begin{array}{c}\mathbf{P} \\
\text { Value }\end{array}$} \\
\hline & & \multicolumn{2}{|c|}{ Pil KB } & \multicolumn{2}{|c|}{ KB Suntik } & \multicolumn{2}{|c|}{ IUD } & \multicolumn{2}{|c|}{ Implan } & \multicolumn{2}{|c|}{ MOW } & \multicolumn{2}{|c|}{ Jumlah } & \\
\hline & & $\mathbf{n}$ & $\%$ & $\mathbf{n}$ & $\%$ & $\mathbf{n}$ & $\%$ & $\mathbf{n}$ & $\%$ & $\mathbf{n}$ & $\%$ & $\mathbf{n}$ & $\%$ & \\
\hline 1. & Tinggi & 3 & 100 & 0 & 0 & 0 & 0 & 0 & 0 & 0 & 0 & 3 & 100,0 & \\
\hline 2. & Sedang & 14 & 48,3 & 11 & 37,9 & 0 & 0 & 2 & 6,9 & 2 & 6,9 & 29 & 100,0 & \\
\hline 3. & Rendah & 0 & 0 & 3 & 27,3 & 1 & 9,1 & 6 & 54,5 & 1 & 9,1 & 11 & 100 & 0,004 \\
\hline & Jumlah & 17 & 39,5 & 14 & 32,6 & 1 & 2,3 & 8 & 18,6 & 3 & 7 & 43 & 100,0 & \\
\hline
\end{tabular}

29 responden yang mendapat dukungan sedang dari suami, kurang dari setengahnya menggunakan Pil KB sebanyak 14 responden (48,3\%). Kemudian 11 responden (37,9\%) 
JOURNAL OF NURSING PRACTICE AND EDUCATION

VOL. 01 NO. 01, DESEMBER 2020
Ciptaan disebarluaskan di bawah

Lisensi Creative Commons Atribusi-

NonKomersial-BerbagiSerupa 4.0

Internasional.

menggunakan KB Suntik, tidak ada satupun responden yang menggunakan KB IUD serta responden yang menggunakan KB implan dan MOW sama besar masing-masing sebanyak 2 responden $(6,9 \%)$.

Berdasarkan hasil analisis chi-square diperoleh $\mathrm{p}$ value $=0,004$ artinya ada hubungan antara dukungan suami dengan pemilihan metode kontrasepsi.

\section{Pembahasan}

Dukungan suami sangat diperlukan dalam melaksanakan Keluarga Berencana. Dukungan suami dapat mempengaruhi perilaku istri. Apabila suami tidak mengizinkan atau mendukung, maka para istri akan cenderung mengikuti dan hanya sedikit istri yang berani untuk tetap memasang alat kontrasepsi. Menurut analisa peneliti hasil penelitian ini menunjukan bahwa sebagian besar suami mendukung istri secara baik atau positif, sehingga ada respon yang baik dari suami untuk istrinya dalam menggunakan alat kontrasepsi. Tingginya dukungan suami terhadap istri pada penelitian ini disebabkan karena perhatian suami yang begitu besar terhadap istri yang ingin menggunakan alat kontrasepsi akan tetapi dukungan suami yang baik mengenai alat kontrasepsi tidak menjamin penggunaan alat kontrasepsi juga baik. Selain peran penting dalam mendukung pengambilan keputusan, peran suami dalam memberikan informasi juga sangat berpengaruh bagi istri.

Seorang wanita seharusnya perlu memiliki kesadaran akan hak-hak reproduksinya artinya seorang wanita juga bebas dari intervensi dalam pengambilan keputusan terkait dengan kesehatan reproduksinya selain itu seorang wanita juga bebas dalam segala bentuk paksaan yang mempengaruhi kehidupan reproduksi seorang perempuan. Keputusan membatasi kehamilan, menunda kehamilan, terkait dengan kesehatan reproduksinya termasuk memilih jenis alat kontrasepsi yang aman dan nyaman dan menjaga keberlangsungan penggunaan kontrasepsi adalah keputusan otonomi seorang wanita dan tidak dipengaruhi oleh lingkungan sosial dan budaya. Menurut peneliti berdasarkan hasil penelitian ini, metode kontrasepsi yang paling dominan digunakan oleh Pasangan Usia Subur (PUS) yang menjadi responden penelitian yaitu suntik dan pil yang termasuk dalam kategori non MKJP, sedangkan tujuan ber-KB pada PUS paling banyak yaitu membatasi kelahiran. Permintaan 
JOURNAL OF NURSING PRACTICE AND EDUCATION

VOL. 01 NO. 01, DESEMBER 2020
Ciptaan disebarluaskan di bawah

Lisensi Creative Commons Atribusi-

NonKomersial-BerbagiSerupa 4.0

Internasional.

$\mathrm{KB}$ dipengaruhi beberapa faktor yaitu akses yang terdiri dari sumber pelayanan dan biaya yang dikeluarkan; nilai anak dan keinginan anak; faktor sosial yang terdiri dari dukungan suami, status ekonomi dan tempat tinggal; serta faktor individu meliputi umur dan pendidikan.

Berdasarkan hasil penelitian diperoleh hasil bahwa adanya hubungan yang signifikan antara dukungan suami dengan pemilihan metode kontrasepsi pada pasangan usia subur di Puskesmas Sunyaragi Kota Cirebon Tahun 2020. Hal ini berarti, semakin tinggi dukungan suami yang diperoleh maka semakin tinggi keikutsertaan PUS untuk melakukan pemilihan kontrasepsi, demikian pula sebaliknya bahwa semakin rendah dukungan suami maka semakin rendah pula keikutsertaan PUS dan pemilihan alat kontrasepsi.

\section{Kesimpulan}

Gambaran dukungan suami di Puskesmas Sunyaragi Kota Cirebon Tahun 2020, menunjukkan bahwa lebih dari sebagian responden mendapatkan dukungan suami dalam kategori sedang $(67,4 \%)$

Gambaran pemilihan metode kontrasepsi pada pasangan usia subur di Puskesmas Sunyaragi Kota Cirebon Tahun 2020, menunjukkan bahwa hampir sebagian responden memilih metode kontrasepsi Pil KB (39,5\%)

Terdapat hubungan yang bermakna antara dukungan suami dengan pemilihan metode kontrasepsi pada pasangan usia subur di Puskesmas Sunyaragi Kota Cirebon Tahun 2020 (p value $=0,000$ ).

\section{Saran}

\section{Bagi Klien dan Keluarga Klien}

Pentingnya peran serta dukungan suami dalam pemilihan metode kontrasepsi yang tepat pada pasangan usia subur.

\section{Bagi Puskesmas}


JOURNAL OF NURSING PRACTICE AND EDUCATION

VOL. 01 NO. 01, DESEMBER 2020
Ciptaan disebarluaskan di bawah

Lisensi Creative Commons Atribusi-

NonKomersial-BerbagiSerupa 4.0

Internasional.

Untuk lebih melibatkan suami dalam pemilihan metode kontrasepsi dan menjadikan hasil penelitian ini sebagai masukan dalam penyusunan program pemilihan kontrasepsi yang tepat bagi pasangan usia subur (PUS).

\section{Bagi Program Studi Ilmu Keperawatan}

Menjadikan hasil penelitian ini untuk menambah wawasan keilmuan mahasiswa khususnya program studi ilmu keperawatan dan sebagai bahan referensi dalam penelitian lanjutan mengenai hubungan dukungan suami dengan pemilihan metode kontrasepsi pada pasangan usia subur.

\section{Bagi Peneliti Selanjutnya}

Mengembangkan penelitian yang serupa menjadi lebih sempurna dengan menjadikan hasil penelitian ini sebagai bahan referensi.

\section{Daftar Pustaka}

Badan Pusat Statistik. (2015). Statistik Indonesia 2015. Badan Pusat Statistik. https://doi.org/0126-2912

BKKBN Provinsi Jawa Barat. (2020). Jumlah PUS dan Peserta KB Aktif.

Kadarisman, Y., \& Kurniawati, Y. (2014). Analisis Faktor-Faktor Yang Mempengaruhi Ketidakikutsertaan Pasangan Usia Subur (Pus) Dalam Program Keluarga Berencana Di Kecamatan Pujud Kabupaten Rokan Hilir. Riau University.

Yusuf, M. (2020). Hubungan Karakteristik Geografi Keluarga terhadap Pemilihan Alat Kontrasepsi Perempuan di Kota Serang. JIPAGS (Journal of Indonesian Public Administration and Governance Studies), 3(2). 